\title{
Successful Treatment with Intravenous and Intravascular Cidofovir for BK Virus-Associated Hemorrhagic Cystitis after Allogeneic Hematopoietic Stem Cell Transplantation: A Case Report
}

\author{
Azim Mehrvara, b Ali Naderia Narjes Mehrvar ${ }^{a} \quad$ Mahyar Nourian $^{a}$ \\ aMahak Hematology Oncology Research Center (Mahak-HORC), Mahak Hospital, Shahid \\ Beheshti University of Medical Sciences, Tehran, Iran; ${ }^{b}$ Research Center for Cancer \\ Screening and Epidemiology, AJA University of Medical Sciences, Tehran, Iran
}

\section{Keywords}

Cidofovir - Acute myeloid leukemia - BK virus · Hematopoietic stem cell transplantation ·

Hematuria

\begin{abstract}
BK virus rarely causes disease but is typically associated with patients who have had a transplant. The cornerstone of therapy is reduction in immunosuppression. A recent surge in BKVAN correlates with use of potent immunosuppressant drugs, such as tacrolimus and mycophenolate mofetil. Studies have not shown any correlation between BKVAN and a single immunosuppressive agent but rather the overall immunosuppressive load. A 12-year-old male with recurrent acute myeloblastic leukemia (M4) was undergoing chemotherapy regimen at MAHAK Pediatric Cancer Treatment and Research Center. Following 28 days of allogenic transplantation with protocol BU/CY/Mel from his brother, he had severe hematuria in urine. So he was screened for the reason of hematuria. The results of screening showed that he had positive BK virus in urine (viral load PCR tests: $7128037228 \mathrm{IU} / \mathrm{ML}$ ). According to grade IV hemorrhagic cystic, cidofovir was administered for the first time as IV and then 2 times as intravesical. After the administration of cidofovir, the symptoms of hematuria improved and the load of BK virus decreased that finally accounted as zero. Cidofovir could be the target issue in patients' recovery. Authors suggest further evaluations of cidofovir both in allogeneic stem cell transplantation setting and in renal allograft patients to consider its impact on BKV and nephropathy.
\end{abstract}




\section{Introduction}

BK virus is a human polyomavirus which is acquired in early childhood and remains lifelong latent in the genitourinary system [1]. The BK virus, a member of the polyomavirus family, has uncommon significant consequences of infection [2-4]. BK virus rarely causes disease but is typically associated with patients who have had a transplant [5]. Many people who are infected with this virus are asymptomatic. If symptoms do appear, they could have mild respiratory infection or fever [6].

The cornerstone of therapy is reduction in immunosuppression. A recent surge in BKVAN correlates with the use of potent immunosuppressant drugs, such as tacrolimus and mycophenolate mofetil. Studies have not shown any correlation between BKVAN and a single immunosuppressive agent but rather the overall immunosuppressive load [7].

This study reports the management and care of a boy with acute myeloblastic leukemia (AML) who conferred with BK virus during his treatment. The mentioned patient had been admitted at MAHAK Pediatric Cancer Treatment and Research Center (MPCTRC) for diagnosis and treatment.

\section{Case Description}

A 12-year-old male, the first child of nonfamilial marriage, had been referred to MPCTRC at May 2017. He did not have any history of familial cancer but showed symptoms of fatty liver grade II. His father has minor thalassemia and the mother has Familial Mediterranean Fever.

At the time of referring at MPCTRC, he was diagnosed with AML-M4 at May 2017. His chemotherapy was administered based on AML-BFM 98 and during the regimen; he had cranial radiotherapy with 12 Gray at October 2017.

Unfortunately, the patient had relapsed at July 2018 and was treated with FLAG protocol. At the time of finalizing induction phase, he was transplanted with protocol BU/CY/Mel. Peripheral Blood Stem Cell Transplantation was collected from full match $(10 / 10) 4$ years old brother in September 2018.

One month after transplantation, the patient admitted due to gross hematuria and clot in urine (grade IV hemorrhagic cystitis [HC]). Urine and plasma analysis showed that BK virus was not detectable in his plasma instead the viral load in urine by quantitative real-time PCR was positive and very high (7.128.037.228 IU/ML). BK VAHC responded dramatically to intravenous $(0 / 68 \mathrm{mg} / \mathrm{kg}=75 \mathrm{mg}$ ) and intravesical (after rising creatinine and 4 times hemodialysis) 3 times which respectively $(0 / 27 \mathrm{mg} / \mathrm{kg}=30 \mathrm{mg}, 0 / 68 \mathrm{mg} / \mathrm{kg}=75 \mathrm{mg}$ and $0 / 68$ $\mathrm{mg} / \mathrm{kg}=75 \mathrm{mg}$ ) cidofovir.

Other treatments consisted of Intravenous immunoglobulin and intravesical Ciprofloxacin long term. Bladder irrigation was performed with Hyaluronic Acid. Patient took 71 units of irradiated single donor platelet and 35 units irradiated packed cell council collection of gross hematuria. Figure 1 shows the summary of patient's treatment and follow-up. At present (23 months after transplant), the patient is in good condition without any complications and all of the drugs are discontinued.

\section{Informed Consent}

Written informed consent was obtained from the parents of the patient for publication of this case report and any accompanying images.

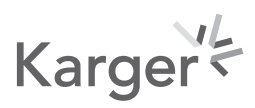




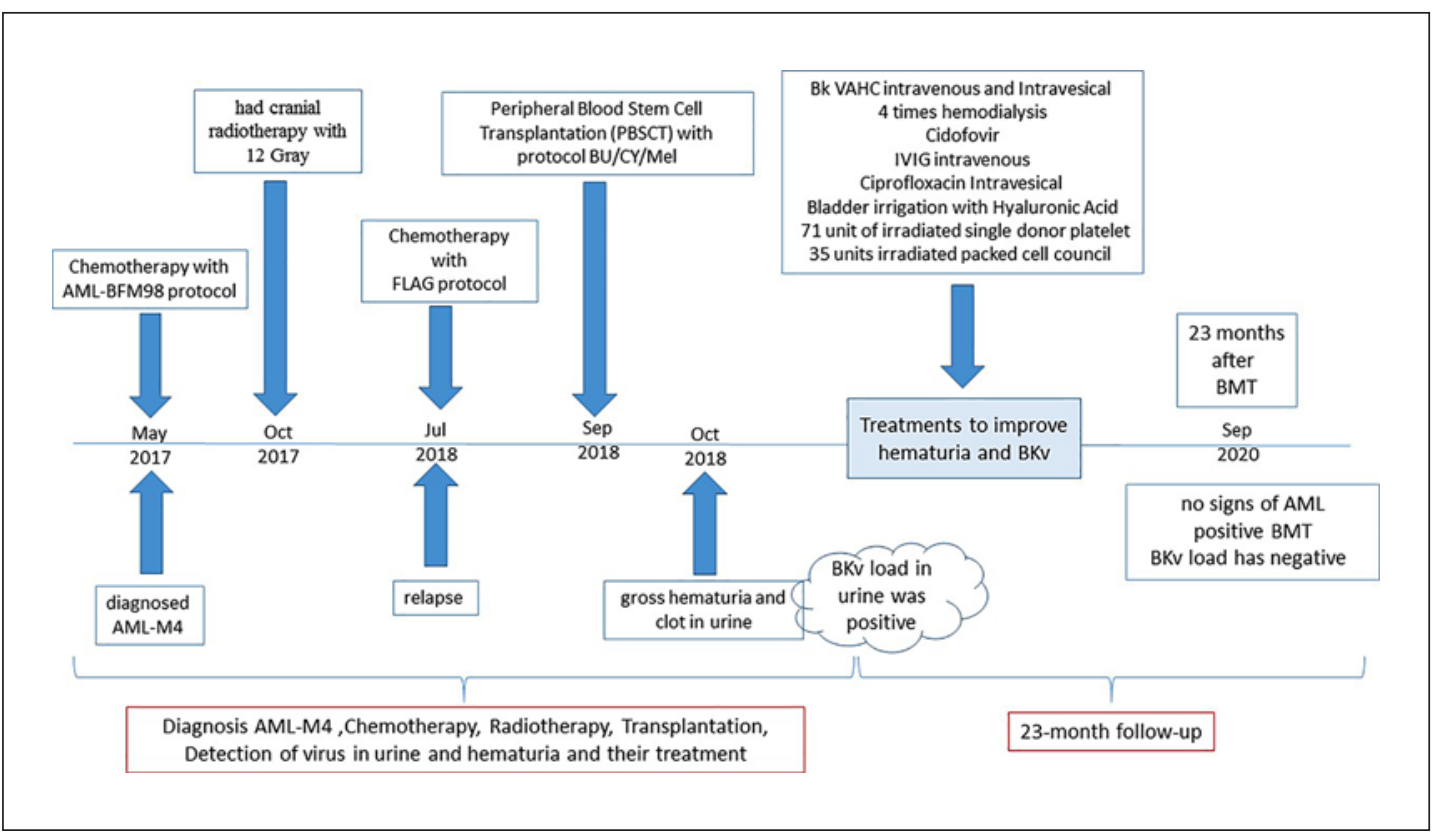

Fig. 1. A summary of the time of diagnosis, treatment process, and patient recovery.

\section{Discussion}

After allogeneic transplant, immunosuppression and pro-inflammatory cytokines stimulate high-level BKV viral replication that could be contributed to the severity of symptoms in HC [8]. A study was conducted in 2014 with the subject of assess and quantify the incidence, severity, risk factors, and outcome of clinical BKV disease after allogeneic HSCT in a contemporary cohort. All patients (491 patients transplanted) who underwent an initial allogeneic HSCT between January 1, 2010, and December 31, 2011, at Dana-Farber Cancer Institute/ Brigham and Women's Hospital were identified through the data repository of the DanaFarber Cancer Institute/Brigham and Women's Hospital HSCT program. BKV disease occurred in 78 patients $(15.9 \%)$. In summary, they concluded that BKV disease is a common complication of HSCT [9].

In another study published in 2006, a 25-year-old male with acute lymphoblastic leukemia became infected with the BK virus after allogeneic stem cell transplantation that was cured by the cidofovir bladder instillation [10].

One study reported 3 cases of AML that became infected with the virus after allogeneic stem cell transplant. It was conducted to emphasize that cidofovir with reducing immunosuppressive treatment will be a good alternative in the therapy of $\mathrm{HC}$ associated with BK virus in the allogeneic stem cell transplant recipients [1]. In all cases, the virus was found in urine after allogeneic stem cell transplant recipients.

In our study, the case is a 12-year-old child. Recent tests have shown no signs of AML in the patient, indicating a positive BMT, and no evidence of BK virus in the plasma or urine of the patient, indicating a positive effect of Cidofovir and, of course, its proper injection. Further investigations are needed to clarify its efficacy and whether earlier instillation in asymptomatic viremia can prevent development of more tissue damage.

\section{Karger'}




\section{Case Reports in Oncology}

\begin{tabular}{l|l}
\hline Case Rep Oncol 2021;14:892-895 \\
\hline DOI: 10.1159/000516269 & $\begin{array}{l}\text { @ 2021 The Author(s). Published by S. Karger AG, Basel } \\
\text { www.karger.com/cro }\end{array}$ \\
\hline
\end{tabular}

Mehrvar et al.: Cidofovir Treatment for BK Virus following HSCT

\section{Acknowledgement}

This research was supported by Mahak-Hematology Oncology Research Center (MahakHORC).

\section{Statement of Ethics}

Written informed consent was obtained from the parents of the patient for publication of this case report and any accompanying images. The study protocol was approved by the Ethics Committee of MPCTRC No. HORC-009-04/2020 and was performed in accordance with the revised Helsinki Declaration.

\section{Conflict of Interest Statement}

The authors have no conflicts of interest to declare.

\section{Funding Sources}

The authors have no other financial involvement with any organization or entity with a financial interest or conflict with the subject matter or materials discussed in the manuscript apart from those disclosed. No writing assistance was utilized in the production of this manuscript.

\section{Author Contributions}

Azim Mehrvar: study conception and design and case treatment, Ali Naderi: treatment of the case, Narjes Mehrvar: manuscript editing, Mahyar Nourian: study conception and design, acquisition of data and analysis, manuscript writing and editing.

\section{References}

1 Mert D, Batgi H, Merdin A, Çeken S, Dal MS, Tekgündüz E, et al. BK virus-associated hemorrhagıc cystitis in patients with allogeneic hematopoietic cell transplantation: report of three cases. Hematol Rep. 2017;9(2):7205.

2 Randhawa PS, Demetris AJ. Nephropathy due to polyomavirus type BK. Waltham, MA: Massachusetts Medical Society; 2000.

3 Pasternak J, Kliszczewska E, Polz-Dacewicz M. BK virus in cancer development. Curr Issues Pharm Med Sci. 2018;31(2):65-8.

4 Tagliapietra A, Rotondo J, Bononi I, Mazzoni E, Magagnoli F, Maritati M, et al. Footprints of BK and JC polyomaviruses in specimens from females affected by spontaneous abortion. Hum Reprod. 2019;34(3):433-40.

5 Pursell K. BK virus and its role in hematopoietic stem cell transplantation: evolution of a pathogen. Curr Infect Dis Rep. 2014;16(8):417.

6 Reploeg MD, Storch GA, Clifford DB. BK virus: a clinical review. Clin Infect Dis. 2001;33(2):191-202.

7 Elfadawy N, Flechner SM, Liu X, Schold J, Tian D, Srinivas TR, et al. The impact of surveillance and rapid reduction in immunosuppression to control BK virus-related graft injury in kidney transplantation. Transpl Int. 2013;26(8):822-32.

8 Leung AY, Suen CK, Lie AK, Liang RH, Yuen KY, Kwong YL. Quantification of polyoma BK viruria in hemorrhagic cystitis complicating bone marrow transplantation. Blood. 2001;98(6):1971-8.

9 Rorije NM, Shea MM, Satyanarayana G, Hammond SP, Ho VT, Baden LR, et al. BK virus disease after allogeneic stem cell transplantation: a cohort analysis. Biol Blood Marrow Transplant. 2014;20(4):564-70.

10 Bridges B, Donegan S, Badros A. Cidofovir bladder instillation for the treatment of BK hemorrhagic cystitis after allogeneic stem cell transplantation. Am J Hematol. 2006;81(7):535-7. 